\title{
QUEENSLAND JOURNAL
}

$\mathrm{OF}$

\section{GuIDANCE \& COUNSELling}

VOLUMe 4 Number 1 NOVEMBer 1990

\section{PUBLISHED FOR}

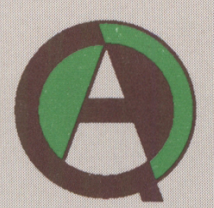

QueEnsland Guidance \& Counselling Association InC 


\section{Queensland Journal of Guidance \& Counselling}

\section{Editor}

John Carroll, Senior Education Officer, Guidance Information Services

\section{Consultant Editors}

\section{Lynne Watts, President}

Queensland Guidance \& Counselling Association, Inc.

Keith Watson, Vice President

Queensland Guidance \& Counselling Association, Inc.

Queensland Guidance \& Counselling Association Inc. 1990

\section{Executive Members}

President

Vice President \&

AGCA Rep.

Secretary

Assistant Secretary

Treasurer

Professional Liaison

Membership Secretary

Country Coordinator

Executive Members
Lynne Watts, Tertiary Education Institute, UQ Keith Watson

Jan Richards, Guidance Officer

Peter Jordan, Guidance Officer

Lorraine Wallis, Guidance Officer

Col McCowan, Principal Education Officer

Deni Castle, Guidance Officer

Kyn Dickinson, Guidance Officer

Ed Bradbury, Guidance Officer

Debbie Heatley, Guidance Officer

Richard Cameron, Principal Education Officer

(Staff Development)

Immediate Past President Keith Watson, Guidance Officer

The Queensland Journal of Guidance and Counselling presents articles of relevance to all areas of guidance and counselling. Papers may address theoretical, practical or training issues, and may focus on educational or psychological topics.

Subscriptions: The Journal is published annually in November. Subscription rates are: Individuals $-\$ 8$ (members of the Australian Guidance and Counselling Association - \$7); Institutions - \$10.

Requests for subscriptions should be sent to:

Ms Lorraine Wallis

Treasurer

Queensland Guidance \& Counselling Association, Inc.

PO Box 351

Everton Park, Q 4053 


\section{QUEENSLAND JOURNAL \\ OF \\ GUIDANCE \& COUNSELLING}

Volume 4 Number 1 November 1990

\section{Contents}

ii Editorial

1 The Future Relationships Scale: Measurement of student perceptions of what makes an adult intimate relationship successful

Kym Dickinson and Barry Tainton

17 "It turned him right around": Social competency

Carol Penn and Peter Stephens

27 Meeting students' needs through a whole school approach to pastoral care

Rosalie Gannon

33 Enchancing adolescents' self-esteem with Rational- Emotive Therapy

Michael J. Fry

47 Cross-cultural counselling

Liz Knox

55 The prevalence and nature of behaviour problems in primary school children in the South Coast Region of Queensland Juanita Muller

69 Using cognitive behaviour training activities and group processes to enhance spelling performance

Robyn Gillies

79 The effectiveness of student tutors in the treatment of speech articulation problems in young school children James J. Jupp, Christine J. Svenson and K. Reed 